\title{
Genetic determinants of the defense response of resistant and susceptible pepper (Capsicum annuum) cultivars infected with Phytophthora capsici (Oomycetes; Pythiaceae)
}

\author{
Y.-L. Zhang, ${ }^{1,2}$, D.-W. Li ${ }^{1,2}$, Z.-H. Gong ${ }^{1,2}$, J.-E. Wang ${ }^{1,2}$, Y.-X. Yin ${ }^{1,2}$ \\ and $\mathbf{J} .-\mathbf{J} . \mathbf{J i} \mathbf{i}^{1,2}$ \\ ${ }^{1}$ College of Horticulture, Northwest A\&F University, Yangling, Shaanxi, China \\ ${ }^{2}$ State Key Laboratory of Crop Stress Biology in Arid Areas, \\ Northwest A\&F University, Yangling, Shaanxi, China \\ Corresponding author: Z.-H. Gong \\ E-mail: zhgong@nwsuaf.edu.cn \\ Genet. Mol. Res. 12 (3): 3605-3621 (2013) \\ Received October 17, 2012 \\ Accepted February 16, 2013 \\ Published September 13, 2013 \\ DOI http://dx.doi.org/10.4238/2013.September.13.5
}

\begin{abstract}
Based on culture isolation and morphological observation blight-infected pepper plants in Shaanxi Province, China, we identified the pathogen causing pepper phytophthora blight as Phytophthora capsici. Varieties that differed in resistance (CM334, PBC602, and B27) were inoculated with this pathogen. The root activity of resistant CM334 variety was the highest while that of susceptible B27 variety was the lowest. Also, significant differences in the activity of POD, PAL, and $\beta$-1,3-glucanase were found; there was a positive correlation between disease resistance and activity of these three enzymes. We inhibited mycelial growth and sporangia formation of $P$. capsici using crude $\beta$-1,3-glucanase and PAL enzymes isolated from the resistant variety CM334 after it had been inoculated with P. capsici. These two enzymes had a synergistic effect on inhibition of $P$. capsici mycelial growth and sporangia formation. Expression of the defensive genes CaPOl, $C a B G L U, C a B P R 1$, and $C a R G A$ in the three varieties was higher in the
\end{abstract}


leaves than in the roots. All three genes were upregulated in infected leaves and roots of the pepper plants, always expressing at higher levels in the resistant cultivar than in the susceptible cultivar, suggesting that the differences in resistance among the pepper genotypes involve differences in the timing and magnitude of the defense response.

Key words: Capsicum annuum; Phytophthora blight; Phytophthora capsici Leonian; Enzyme activity;

Defense-related gene expression

\section{INTRODUCTION}

Phytophthora blight of pepper (Capsicum annum L.) caused by the oomycete plant pathogen Phytophthora capsici is one of the most destructive diseases all over the world (Hwang and Kim, 1995; Ristaino and Johnston, 1999; Lee et al., 2001; Hausbeck and Lamour, 2004). P. capsici attacks the roots, stems, leaves, and fruits of the pepper plant. It is also pathogenic on tomato, eggplant, cucumber, watermelon, pumpkin, squash, and cocoa (Black et al., 1991; Biles et al., 1995; Holmes et al., 2001; Tyler, 2002; Oelke and Bosland, 2003). This disease can affect the plant at any stage of development causing damping-off, seedling blight, foliar blight, and wilting followed by plant death. Infection of mature plants materializes as dark, rapidly expanding, water-soaked lesions (Baysal et al., 2005; Candole et al., 2012; Kousik et al., 2012).

Peroxidase (POD) is an oxido-reductive enzyme that participates in the cell wall polysaccharide processes such as oxidation of phenols, suberization, and lignification of host plant cells during the defense reaction against pathogenic agents (Kolattukudy et al., 1992; Chittoor et al., 1999). Resistance is associated with the induction of peroxidase (Cloud and Deverall, 1987) in host tissues. Accumulation of lignin and phenolic compounds has been correlated with disease resistance in a number of plant-pathogen interactions.

Phenylalanine ammonia-lyase (PAL) is the entry-point enzyme in the phenylpropanoid biosynthesis pathway and its presence has been demonstrated in all higher plants (Chen and McClure, 2000), some fungi and yeast (D'Cunha et al., 1996). Studies in several different species of plants have shown that the activity of PAL increases if they are subjected to biotic and abiotic factors, such as fungal infection (Kombrink and Somssich, 1995) and low temperature (Benkeblia, 2000; Jung et al., 2004).

$\beta-1,3-$ Glucanase is one of the most well-known pathogenesis-related (PR) proteins that have been found in seeds or leaves (Suo and Leung, 2001; Wu and Bradford, 2003; Saikia et al., 2005). An apparent role for $\beta$-1,3-glucanase is to defend against phytopathogens such as fungi (Egea et al., 1999; Funnell et al., 2004; Wakelin and Leung, 2009).

However, little is known about the changes in POD, $\beta$-1,3-glucanase, and PAL activities in host plants as related to inoculation with phytopathogen in pepper plants. The present study focused on the investigation of the variations in enzyme activity after inoculation with $P$. capsici, inhibitory effect of crude enzyme on mycelial growth and sporangia formation of P. capsici, and the analysis of expression patterns of four defense-related genes in a resistant (CM334), a moderately resistant (PBC602), and a susceptible (B27) pepper cultivar (C. annuum), after inoculation with $P$. capsici, using quantitative real-time polymerase chain reaction (qRT-PCR). 


\section{MATERIAL AND METHODS}

\section{Plant materials, pathogen, and inoculation}

C. annuum CM334 (highly resistant), PBC602 (moderately resistant), and B27 (susceptible) to $P$. capsici were used for infection with $P$. capsici. Plants were grown in a growth chamber at $25^{\circ} \mathrm{C}$ under 16 and $8 \mathrm{~h}$ of light and dark, respectively. At the six-leaf stage, pepper plants were inoculated with $P$. capsici (Yeom et al., 2011).

P. capsici-infected plants were collected from the experimental field of Northwest A\&F University (Yangling, P.R. China). The pathogen was isolated from plants by taking small cuttings from lesions at the crown, soaking them in $75 \%$ alcohol for $30 \mathrm{~s}$, rinsing them with sterile water for $30 \mathrm{~s}$, and in 10\% bleach for 2-3 min, and washing 2-3 times with sterile water. Finally, the cuttings were dried with sterile absorbent paper and then transferred to the center of PDA (potato-dextrose agar) Phytophthora-selective plate medium (200 g/L potatoes boiled $30 \mathrm{~min}$ and filtered, $17 \mathrm{~g} / \mathrm{L}$ agar, $20 \mathrm{~g} / \mathrm{L}$ sucrose, $50 \mathrm{mg} / \mathrm{mL}$ penicillin, and $100 \mathrm{mg} / \mathrm{mL}$ rifampicin). From each plate showing mycelial growth, a 4-mm plug was aseptically transferred to the center of a new PDA plate that did not contain any antibiotics. Plates were sealed with Parafilm (Flexible Packaging, BEMIS; Neenah, WI) to prevent contamination and desiccation. The isolate was maintained on PDA slants at $4{ }^{\circ} \mathrm{C}$ and was grown on PDA plates at $25-26^{\circ} \mathrm{C}$ in the dark.

To confirm that the Phytophthora isolates were indeed P. capsici, the isolated and purified pathogens were cultured 3 days on PDA in the dark at $25-26^{\circ} \mathrm{C}$ to observe the color and the characteristics of the colony. Afterwards, it was incubated under continuous light for 5-7 days, the purified pathogens overspreading the culture dish $(9 \mathrm{~cm} \mathrm{x} 9 \mathrm{~cm})$ would form a large sporangium. The mycelium having formed the sporangium was picked and placed on the slides with sterile water to observe the morphology of the sporangium under the microscope.

Zoospore release was induced by chilling cultures at $4{ }^{\circ} \mathrm{C}$ for $30 \mathrm{~min}$ and then incubating at room temperature for 30-60 min. Zoospore concentration was counted using a hemocytometer, and the concentration adjusted to $1 \times 10^{5}$ zoospores $/ \mathrm{mL}$. The seed tray was soaked with water to keep damp before inoculating the plants. Five milliliters of spore suspension were injected in a $3-\mathrm{cm}$ deep hole $3 \mathrm{~cm}$ away from the roots of the seedlings. After inoculation, the soil was kept damp and incubated at $28^{\circ} \mathrm{C}$. Five seedlings from each variety were used with 3 replicates. The samples of leaves and roots at $0,6,12,24,48,72$ and $96 \mathrm{~h}$ after inoculation were taken and stored at $-80^{\circ} \mathrm{C}$.

\section{TTC reduction assay}

P. capsici-infected root samples (300-500 mg) from each time point, including noninfected roots, were washed with sterile water for $10 \mathrm{~min}$. The same samples were incubated with $0.4 \%$ TTC (Sigma-Aldrich, St. Louis) and $5 \mathrm{~mL}$ phosphate buffer (pH 7.0), respectively. In the control, $2 \mathrm{~mL} 1 \mathrm{M} \mathrm{H}_{2} \mathrm{SO}_{4}$ were added and reacted at $37^{\circ} \mathrm{C}$ in the dark for $1 \mathrm{~h}$, shaking

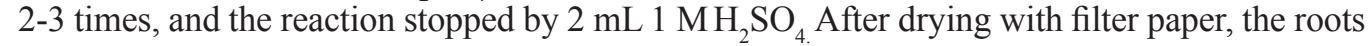
were ground with 1-2 mL ethyl acetate. The homogenates were collected in a 10-mL centrifuge tube which was filled to the $10 \mathrm{~mL}$ volume with ethyl acetate. The homogenate was centrifuged at $4000 \mathrm{rpm}$ for $10 \mathrm{~min}$. Absorbance was read at $485 \mathrm{~nm}$ (model UV-1700 PharmanSpec; SHIMADZU, Japan). TTC reduction assays were performed three times in each independent treatment according to Jung et al. (2004). 


\section{Enzymatic assays}

\section{Assay of peroxidase activity}

Volumes of $28 \mu \mathrm{L}$ guaiacol and $19 \mu \mathrm{L} 30 \% \mathrm{H}_{2} \mathrm{O}_{2}$ were added to $50 \mathrm{~mL} 100 \mathrm{mM}$ PBS to prepare the substrate solution. The reaction mixture containing $3 \mathrm{~mL}$ substrate and $1 \mathrm{~mL}$ crude enzyme were shaken and optical density at $470 \mathrm{~nm}$ was read at intervals of $30 \mathrm{~s}$, for $3 \mathrm{~min}$. The control did not contain the enzyme. Each 0.01 increase in OD at $470 \mathrm{~nm}$ was defined as one unit. Peroxidase activity was determined as the rate in increase in enzyme activity (U) per minute per gram fresh weight $\left(\mathrm{U} \cdot \mathrm{min}^{-1} \cdot \mathrm{gFW}^{-1}\right)$ according to Hammerschmidt et al. (1982).

\section{Assay of PAL}

The reaction mixture containing $0.5 \mathrm{~mL}$ crude enzyme, $0.5 \mathrm{~mL}$ borate buffer, $2 \mathrm{~mL}$ water and $1 \mathrm{~mL} 0.02 \mathrm{M}$ phenylalanine (with no enzyme in the control) was incubated at $30^{\circ} \mathrm{C}$ for $30 \mathrm{~min}$. Absorbance was determined at $290 \mathrm{~nm}$, for three repeats in each treatment according to Idoia et al. (2006).

\section{Assay of $\beta$-1,3-glucanase}

$\beta-1,3$-Glucanase activity was measured according to Egea et al. (1999). A volume $(0.2 \mathrm{~mL})$ of $1 \mathrm{mg} / \mathrm{mL}$ laminarin dissolved in $0.05 \mathrm{mM}$ sodium acetate buffer was boiled for $2 \mathrm{~min}$, followed by the addition of $0.1 \mathrm{~mL}$ enzyme preparation, and then incubated at $37^{\circ} \mathrm{C}$ for $1.5 \mathrm{~h}$ and boiled for $5 \mathrm{~min}$. A volume of $(0.1 \mathrm{ml})$ the reaction mixture was boiled for $5 \mathrm{~min}$ after the reaction was stopped by 0.1 $\mathrm{mL}$ 3, 5-dinitrosalicylic acid (DNS). The absorbance of the mixture which was cooled to room temperation was measured at $540 \mathrm{~nm}$. In the control, the enzyme preparation was substituted by $0.1 \mathrm{~mL}$ inactive enzyme preparation. An enzyme activity unit (U) was defined as the enzyme amount needed to produce $1 \mu \mathrm{mol}$ reducing sugar per minute when reacted with the substrate.

\section{Effect of $\beta$-1,3-glucanase and PAL crude enzymes}

\section{Effect on sporangium formation of $P$. capsici}

The zoospore suspension was prepared according to Zuo et al. (2001), in which 10 mycelia were cultured in a Petri dish with $10 \mathrm{~mL}$ sterile water, changing the water every two days. After changing the water twice, mycelial masses can produce sporangia. On the third time, $\beta$-1,3-glucanase, PAL and the enzyme mixture of equal volume of $\beta$-1,3-glucanase

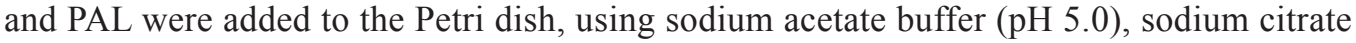
buffer ( $\mathrm{pH} 5.0)$ and the two buffer mixture $(\mathrm{V} 6 \mathrm{~V}=161)$ as the control. The crude enzymes were cultured at $25^{\circ} \mathrm{C}$ with different concentrations (100, 80, 50, 20 and 10\%). Afterwards, sporangium formation was observed under a light microscope every $6 \mathrm{~h}$. Each mycelial mass was observed in five fields until the sporangium of the control was completely released. The amount of the sporangium was used to assess the inhibition in each treatment with three repetitions. 


\section{Effect on mycelial growth of P. capsici}

P. capsici was placed in the center of the 90-mm PDA plate and allowed to grow at $25^{\circ} \mathrm{C}$ for 3-4 days. A volume $(50 \mu \mathrm{L})$ of $\beta$-1,3-glucanase, PAL and the two enzyme mixture $(\mathrm{V} 6 \mathrm{~V}=161)$ were separately injected into the three wells at $1.0 \mathrm{~cm}$ around the colony. The solution with two enzyme extracted mixture buffer $(\mathrm{V} 6 \mathrm{~V}=161)$ was injected into the fourth well, used as control. The culture medium was incubated at $25^{\circ} \mathrm{C}$ for $3-5$ days after sealed with Parafilm, and mycelial growth diameter was measured.

\section{RNA extraction and cDNA synthesis}

The treated leaves and roots were collected at $0,6,12,24,48,72$ and $96 \mathrm{~h}$ after inoculation with P. capsici, and total RNA was isolated using Trizol ${ }^{\mathbb{B}}$ reagent (Invitrogen Carlsbad, CA, USA) according to the manufacturer instructions. Reverse transcription was carried out using a PrimeScript ${ }^{\mathrm{TM}}$ First Strand Complementary DNA (cDNA) Synthesis kit (TaKaRa, Japan). The concentrations of total RNA and cDNA were measured spectrophotometrically using a NanoDrop instrument (Thermo Scientific NanoDrop 2000C Technologies, Wilmington, DE, USA), and the purity was assessed using the $\mathrm{A}_{260} /{ }_{280}$ and $\mathrm{A}_{260}{ }_{230}$ ratios determined with NanoDrop.

\section{Primer design and qRT-PCR for gene expression analysis}

qRT-PCR analysis was performed using combinations of gene-specific primers for each cDNA (Table 1). qRT-PCR was performed with an iCycler iQ ${ }^{\mathrm{TM}}$ Multicolor PCR Detection System (Bio-Rad, Hercules, CA, USA). qRT-PCR was carried out with cDNA in triplicate in 96-well plates using SYBR ${ }^{\circledR}$ Premix Ex Taq ${ }^{\mathrm{TM}}$ II (TaKaRa, Japan). Each reaction $(20 \mu \mathrm{L})$ consisted of 10 $\mu \mathrm{L}$ SYBR ${ }^{\circledR}$ Premix Ex Taq ${ }^{\mathrm{TM}}$ II, $2 \mu \mathrm{L}$ diluted cDNA, and $0.4 \mu \mathrm{M}$ forward and reverse primers. qRT-PCR cycling conditions were as follows: $95^{\circ} \mathrm{C}$ for $1 \mathrm{~min}$ and 45 cycles of $95^{\circ} \mathrm{C}$ for $15 \mathrm{~s}, 52^{\circ} \mathrm{C}$ for $20 \mathrm{~s}$, and $72^{\circ} \mathrm{C}$ for $30 \mathrm{~s}$. Fluorescence data were collected during the $52^{\circ} \mathrm{C}$ step. As reference genes, expression of ubiquitin-conjugating protein was used for pepper (Wang et al., 2011). Relative quantification of gene expression was calculated with the delta-delta $\mathrm{Ct}$ method.

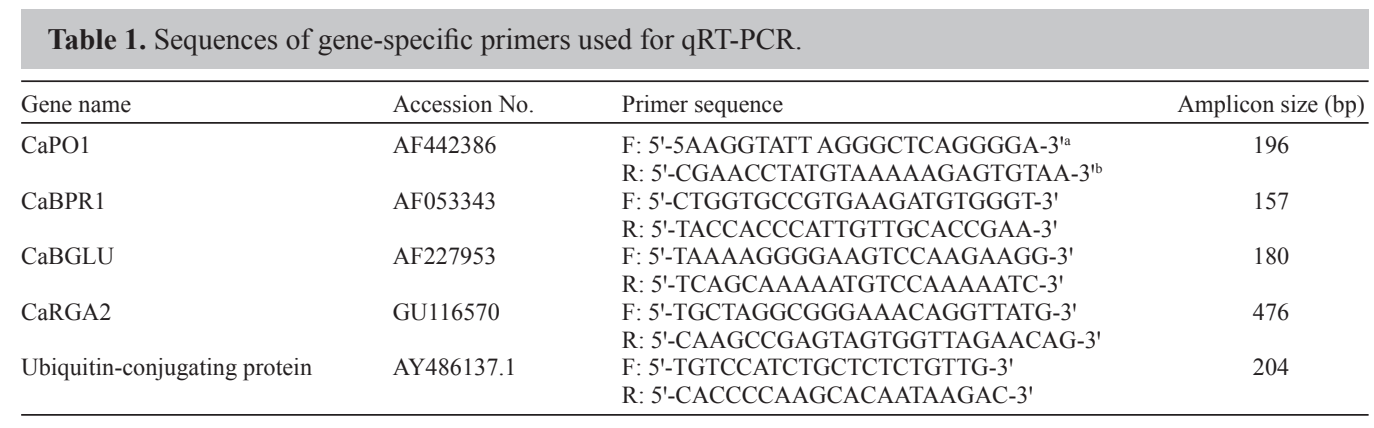

${ }^{\mathrm{a} F}$ orward primer; ${ }^{\mathrm{b}}$ Reverse primer.

\section{Data analysis}

Data presented were mean values \pm S.E.M. (standard error of the mean) for three replicates. 


\section{RESULTS}

\section{Identification of $P$. capsici}

The colonies were white (Figure 1A) with dense mycelium and regular edge after the pathogen was cultured on PDA medium for 3 days. The mycelium was colorless, no phragmosome and had irregular branches (Figure 1B). The variation of the sporangium morphology was greater, most were orbicular-ovate, pyriform and long oval, while few were spherical or irregular, being hazel or colorless. The sporangium showed obvious mastoids (Figure 1C), with most of them having one mastoid, while a few had two mastoids. The zoospores were released from the sporangium in water (Figure 1D). The pathogen resulting in the pepper phytophthora blight in Shaanxi was identified as Phytophthora capsici Leonian, according to the mycelium morphology, sporangium shape and size, and the disease symptom after back inoculation, characteristic of the isolated and purified pathogen.

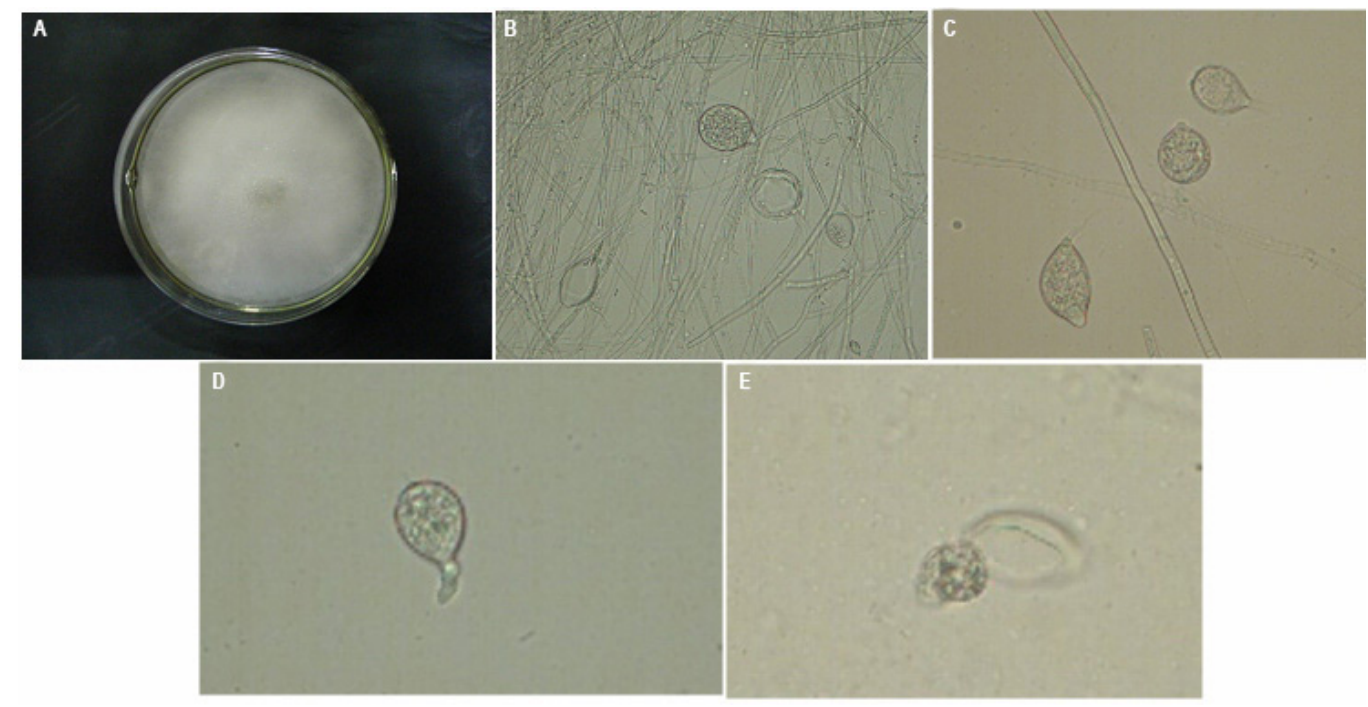

Figure 1. Morphology of colony and sporangia. A. Colony morphology of Phytophthora capsici grown for 7 days on PDA medium; B. Morphology of mycelial and sporangium formation; C. zoosporangia (different shape and mastoid); D. zoospore release; E. completion of the release of zoospores.

\section{Root activity of the different resistant pepper cultivars}

Inoculation of roots of C.annuum CM334, $\mathrm{PBC} 602$, and $\mathrm{B} 27$ cultivars with P. capsici showed disease symptoms, i.e., root dehydration, shrinkage and browning in cultivar B27 at 72 $\mathrm{h}$ post-inoculation (hpi), and leaf wilting at $96 \mathrm{hpi}$, but not in CM334 and PBC602 cultivars at 96 hpi (Figure 2). Infection was verified using 2,3,5-triphenyltetrazolium chloride (TTC) reduction assay as a cell viability indicator. Although no differences were observed above the ground during infection up to $48 \mathrm{hpi}$, the viability of $P$. capsici-infected roots changed dramatically among the three pepper cultivars (Figure 3). Differences in TTC reductase activity in the root 
of the three cultivars, CM334 (the highest), PBC602 and B27 (the lowest) were observed at $6 \mathrm{~h}$ after inoculation, reaching a maximum at $24 \mathrm{~h}$. After inoculation with $P$. capsici, the respiration rate of the root was greatly affected by $P$. capsici, the root color stained by TTC turned weak in all the varieties, especially in the susceptible variety B27, and the root activity of all three cultivars decreased.

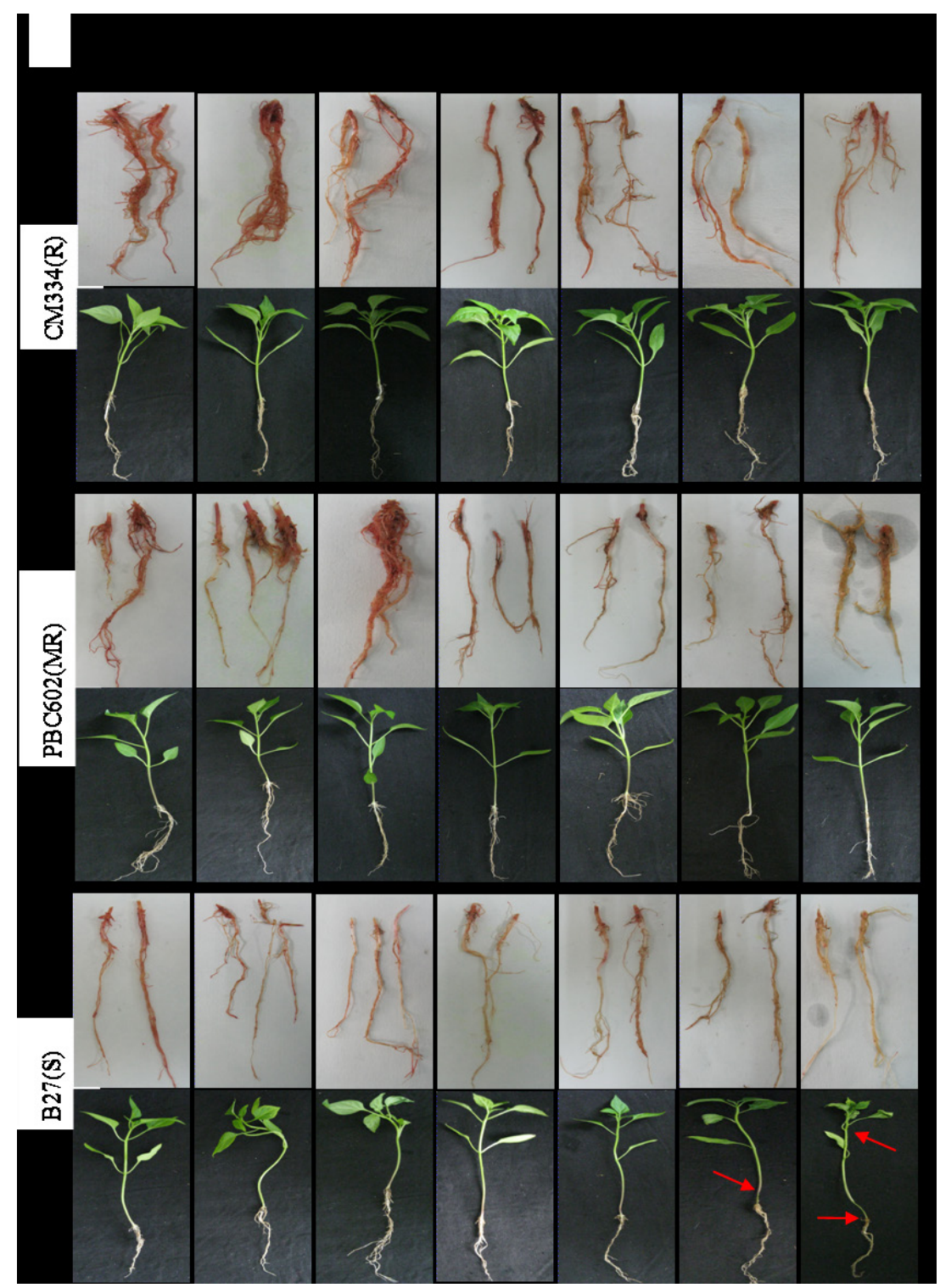

Figure 2. Phenotype of high resistant (Capsicum annuum CM334), moderate resistance (PBC602), and susceptible pepper (B27) roots. Disease symptoms observed at $72 \mathrm{~h}$ postinoculation (hpi) in B27 (susceptible, S) with root dehydration, shrinkage, browning inoculation with zoospores of Phytophthora capsici ( $1 \times 10^{5}$ zoospores $\left./ \mathrm{mL}\right)$, and leaf wilting within 96 hpi, but not in CM334 and PBC602 within 96 hpi. 


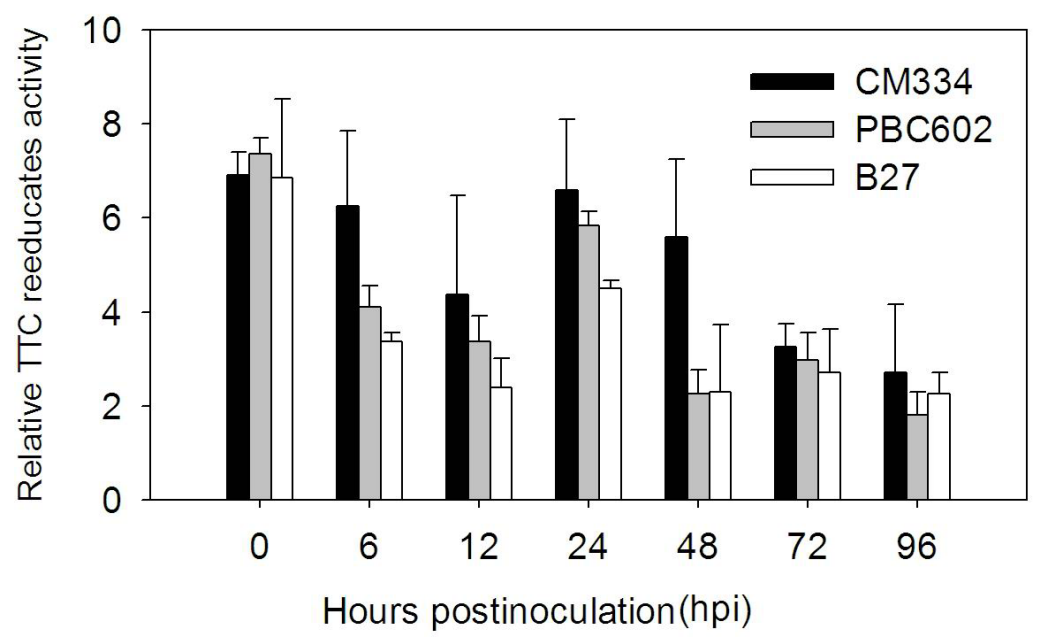

Figure 3. 2,3,5-Triphenyltetrazolium chloride (TTC) reductase activity at different time after inoculation with zoospores of Phytophthora capsici $\left(1 \times 10^{5}\right.$ zoospores $\left./ \mathrm{mL}\right)$ was measured in high resistant, moderate resistance and susceptible pepper roots as cell vitality indicator. Values are reported as means \pm standard deviation.

\section{Changes in activities of peroxidase, phenylalanine ammonia lyase and, $\beta$-1,3-glucanase}

P. capsici inoculation increased POD activity in the three cultivars, compared with the non-inoculated controls (Figure 4A). The highest POD activity in non-inoculated (control) leaves was recorded in the CM334 cultivar. POD activity in CM334 and PBC602 after inoculation with P.capsici was significantly higher than that in B27. Moreover, two peaks of high activity in CM334 were found at 6 and 24 hpi: 7.2 (two times higher than that in the control) and $6.3 \mathrm{U} \cdot \mathrm{min}^{-}$ ${ }^{1} \cdot \mathrm{gFW}^{-1}$, respectively. Comparatively, the enzyme activity in PBC602 reached the highest level at 12 and $48 \mathrm{hpi}: 6.0$ and $6.4 \mathrm{U} \cdot \mathrm{min}^{-1} \cdot \mathrm{gFW}^{-1}$, respectively. After inoculation, POD activity in B27 was not significantly affected, showing a peak $\left(4.5 \mathrm{U} \cdot \mathrm{min}^{-1} \cdot \mathrm{gFW}^{-1}\right)$ after $12 \mathrm{hpi}$.

After CM334, PBC602 and B27 were inoculated with P. capsici, PAL activity of CM334, showed little change from 0 to $24 \mathrm{hpi}$, but it significantly increased and reached a peak at $48 \mathrm{hpi}\left(10.1 \mathrm{U} \cdot \mathrm{h}^{-1} \cdot \mathrm{gFW}^{-1}\right)$ compared with control (Figure 4B). After reaching a peak, enzyme activity gradually decreased with time but was still higher than that of the control. Enzyme activity in PBC602 reached a peak at 6 and $48 \mathrm{hpi}: 7.3 \mathrm{U} \cdot \mathrm{h}^{-1} \cdot \mathrm{gFW}^{-1}$ and $8.5 \mathrm{U} \cdot \mathrm{h}^{-1} \cdot \mathrm{gFW}^{-1}$, respectively. PAL activity in B27 hardly changed before or after inoculation, but it reached the highest level at 96 hpi.

A gradual increase in $\beta$-1,3-glucanase activity was observed in the three cultivars inoculated with P. capsici (Figure 4C). $\beta$-1,3-Glucanase activity reached a maximum level in CM334 at 24 hpi, i.e., $77.2 \mathrm{U} / \mathrm{g}$ (nearly 2 times higher than in B27, 3 times higher than in noninoculated control); it reached the highest level in PBC602 at $6 \mathrm{hpi}$,, i.e., $65.2 \mathrm{U} / \mathrm{g}$; its peak in B27 was at 12 hpi, i.e., $49.0 \mathrm{U} / \mathrm{g}$. $\beta-1,3-$-Glucanase activity in the three resistant varieties first increased and then decreased. Compared with the control, CM334 showed a rapid increase $(192 \%)$ at $24 \mathrm{~h}$. The increase in enzyme activity in PBC602 was highest at 6 hpi (98\%), while that in B27 reached the highest level at $12 \mathrm{hpi}(191 \%)$. Though the enzyme activity of all the samples decreased at $96 \mathrm{hpi}$, there was no significant difference except in CM334. 

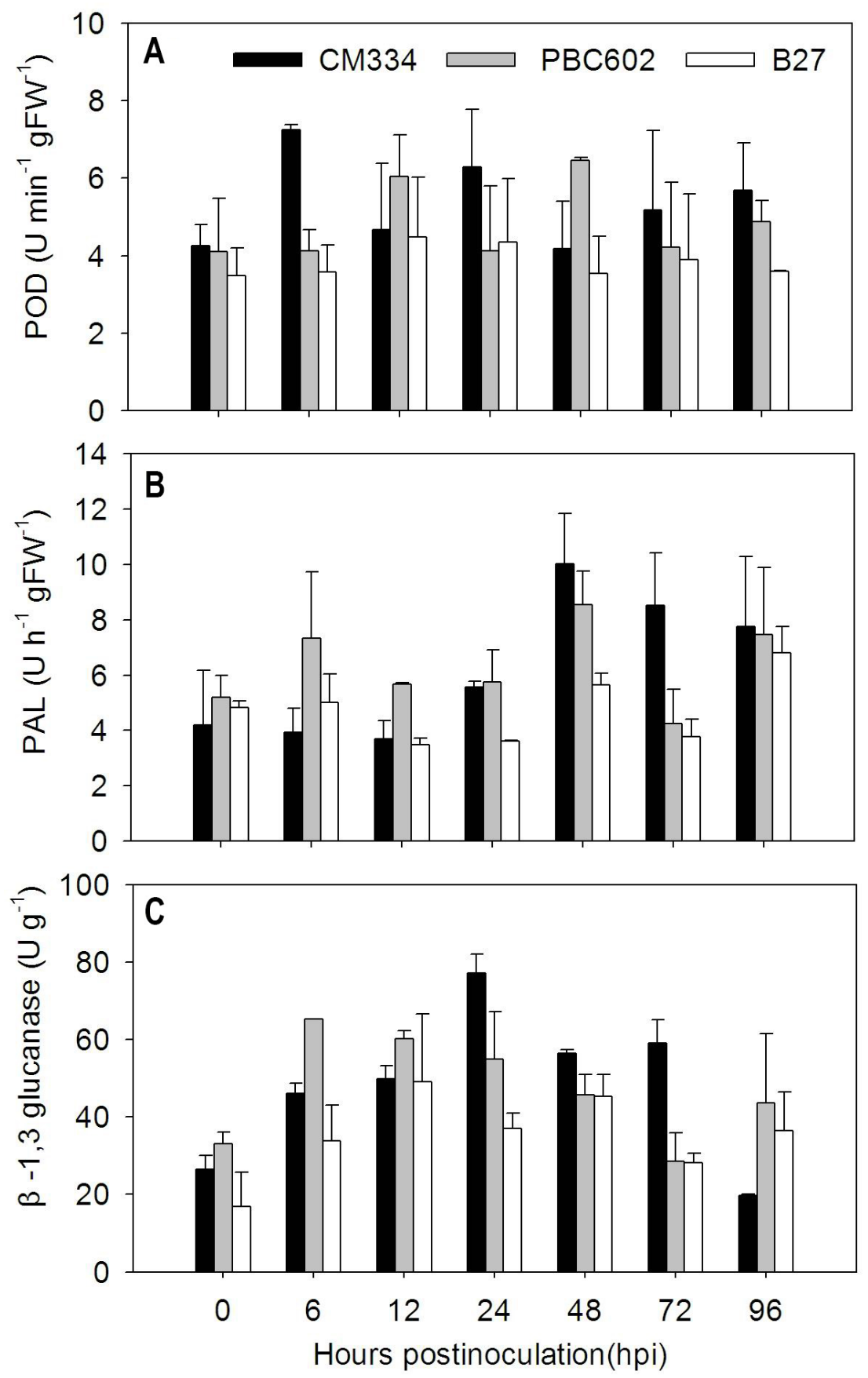

Figure 4. Changes of peroxidase (A), phenylalanine ammonia-lyase (B), and $\beta$-1,3-glucanase activity (C) in high resistant, moderate resistance and susceptible pepper leaves at different stage after inoculation with zoospores of Phytophthora capsici (1 x $10^{5}$ zoospores $\left./ \mathrm{mL}\right)$. 


\section{Inhibitory effect of the crude enzymes of $\beta$-1,3-glucanase and PAL on $P$. capsici}

The crude enzymes with stronger activity, $\beta$-1,3-glucanase $e$ and PAL were extracted from CM334 inoculated with $P$. capsici after 24 and $48 \mathrm{~h}$, respectively, and used to perform the inhibition test on mycelium growth and sporangium formation of P.capsici.

\section{The inhibitory effect on the mycelium growth of $P$. capsici}

$\beta$-1,3-glucanase and PAL had little inhibitory effect on the mycelium growth of $P$. capsici (Figure 5). After injection of the enzyme solution into the wells, the mixed enzyme solution (Figure 5B) exhibited the highest inhibition on mycelium growth, and moreover, the inhibition caused by $\beta$-1,3-glucanase was also more obvious (Figure $5 \mathrm{~A}$ ). On the other hand, the inhibition with PAL was relatively weak (Figure 5C), and the mycelium growth in the control wells was not affected (Figure 5D). All these results showed that the inhibitory effect of the two crude enzymes on the mycelium growth of $P$. capsici had synergistic interaction, meaning that the inhibitory effect of the mixed enzymes was more notable than that of single enzyme solution.

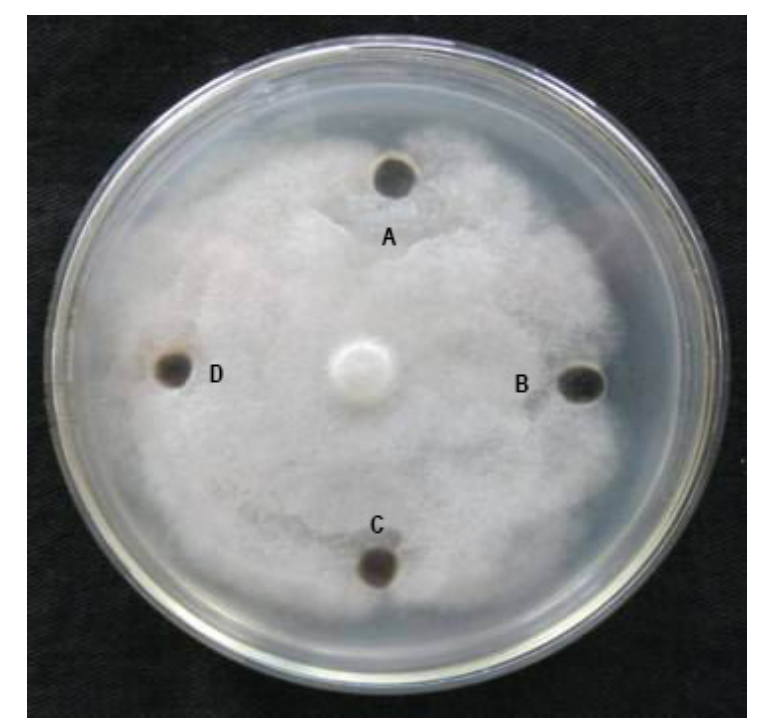

Figure 5. Inhibitory effect of different crude enzyme from pepper leaves against mycelial growth of Phytophthora capsici $i$ on the PDA medium after 5 days. A. $\beta$-1,3-glucanase; B. $\beta$-1,3-glucanase + PAL; C. PAL; D. CK (sodium acetate buffer: sodium citrate buffer $=1: 1$ ).

\section{Inhibitory effect on the sporangium formation of $P$. capsici}

The inhibitory effect of $\beta$-1,3-glucanase, PAL and the mixed enzymes solution on the sporangium formation of $P$. capsici was obviously different (Figure 6). The mixed enzymes showed the strongest inhibitory effect, $92.8 \%$ inhibition with $100 \%$ concentration of enzyme solution and $17.8 \%$ inhibition with only $10 \%$ enzyme solution. The inhibitory 
effect of $\beta$-1,3-glucanase was only next to that of the mixed enzymes solution, $84.6 \%$ inhibition with $100 \%$ concentration and $10 \%$ concentration showing nearly $11.5 \%$ inhibition. The inhibition rate of PAL with 100 and $10 \%$ concentrations were only 60.7 and 4\%, respectively, which indicated the PAL had the weaker inhibitory effect. It could be suggested that the inhibitory effect of the mixed enzymes solution was stronger than that of the single enzymes, while the mixed enzymes had a synergistic inhibitory effect on sporangium formation of P. capsici.

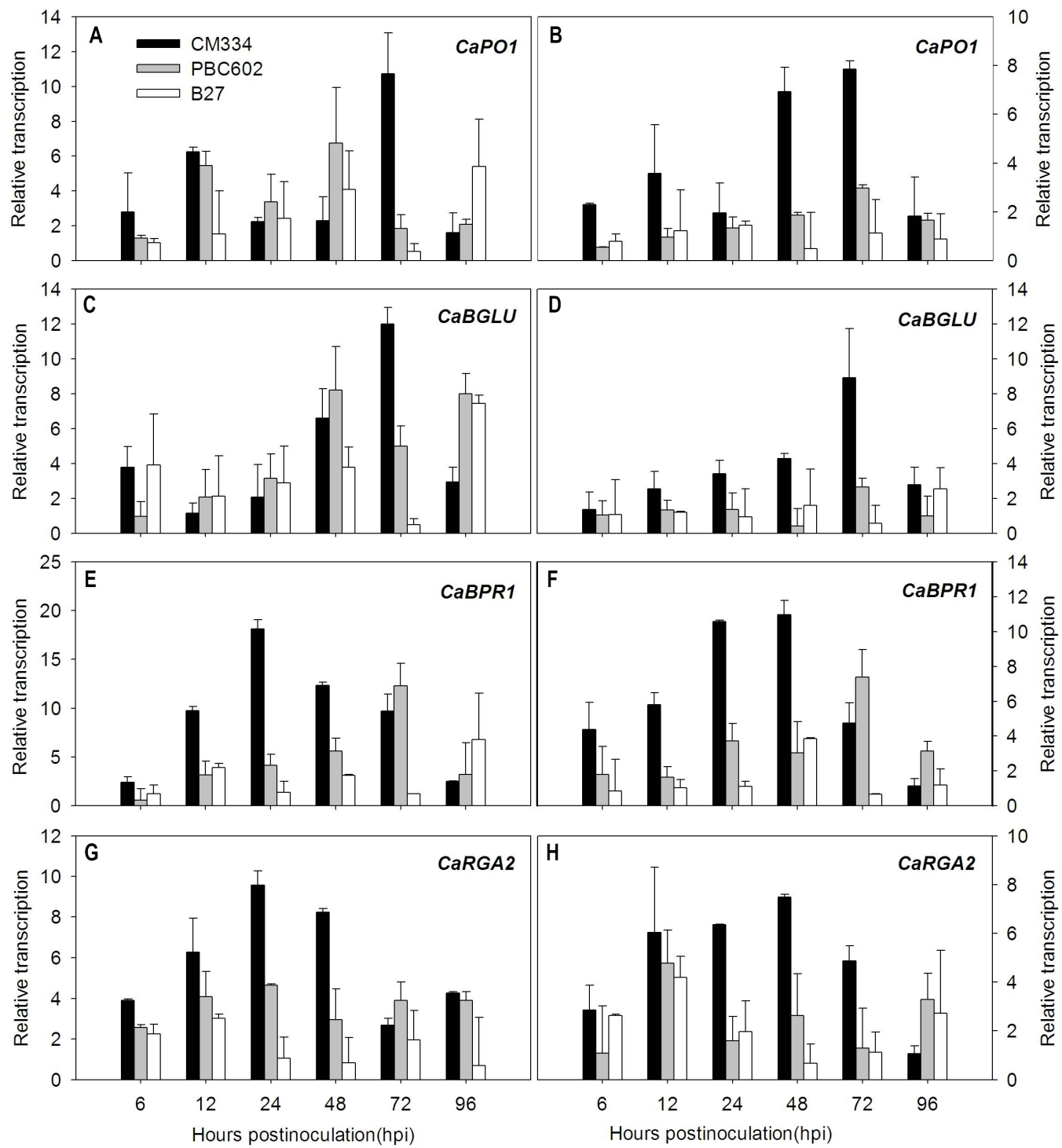

Figure 6. Inhibitory effect of crude enzyme phenylalanine ammonia-lyase 48 hpi and $\beta$-1,3-glucanase 24 hpi extracted from variety of high resistant pepper CM334 against sporangium formation of Phytophthora capsici. 


\section{Gene expression in resistant and susceptible pepper cultivars to P.capsici}

The expression levels of four pepper defense-related genes, $C a B G L U$ encoding a basic $\beta$-1,3-glucanase, $C a P O 1$ encoding peroxidase, $C a B P R 1$ encoding a basic PR-1 protein, and CaRGA2 encoding a blight resistance protein, were analyzed in leaves and roots of three different pepper cultivars infected with $P$. capsici. All the defense-related genes were upregulated in P. capsici-infected leaves and roots of all cultivars (Figure 7).

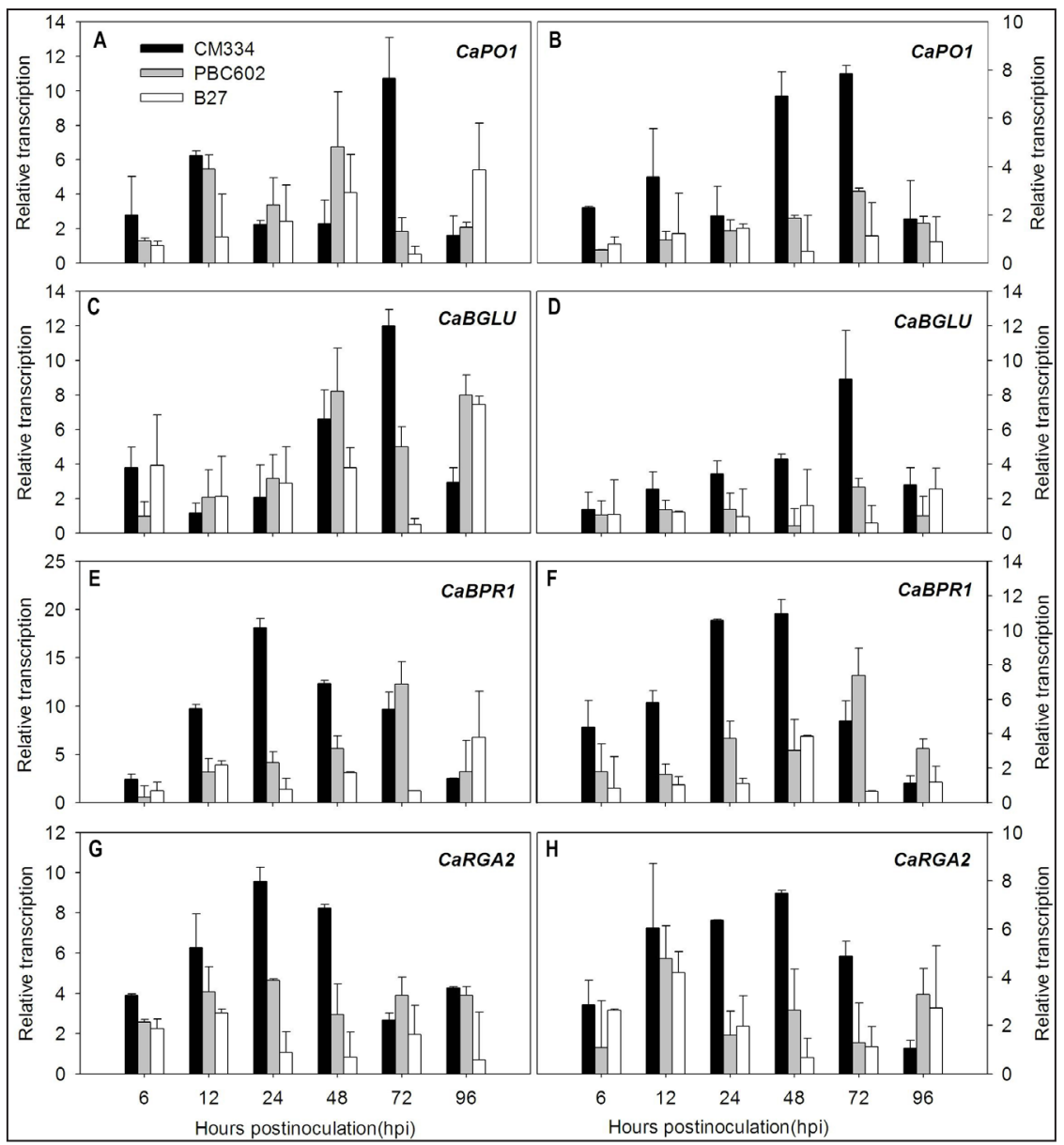

Figure 7. Representative quantitative reverse-transcription polymerase chain reactions (qRT-PCR) of several defense-related genes. Total RNAs were isolated at different time after inoculation with zoospores of Phytophthora capsici $\left(1 \times 10^{5}\right.$ zoospores $\left./ \mathrm{mL}\right)$ from leaves $(\mathbf{A}, \mathbf{C}, \mathbf{E}, \mathbf{G})$ and roots $(\mathbf{B}, \mathbf{D}, \mathbf{F}, \mathbf{H})$ of high resistant, moderate resistance and susceptible pepper plants. The CaPO1, CaBGLU, CaBPR1, and CaRGA2 genes were used to confirm the activation of defense-related genes. qRT-PCRs were performed on cDNA using gene-specific primers for each defense-related gene. Each bar represents the value of relative gene expression at different time points following inoculation of $P$. capsici for indicated defense-related gene between high resistant pepper (black bar, CM334), moderate pepper (gray bar, PBC602), and susceptible pepper (white bar, B27) plants. The expression of defense-related genes was normalized to the expression of ubiquitin-conjugating protein. Values were calculated for defense-related genes following three replications and standard deviations are shown. 
The gene expression of $\mathrm{CaPO}$ in the leaves (Figure 7A) of all the three cultivars was higher than that in the roots (Figure 7B); meanwhile, in the leaves and roots of resistant cultivar CM334, gene expression had a double-peak curve, where the peaks appeared at 12 and $72 \mathrm{hpi}$ (10.7 and 7.9 times higher than that of the control), respectively. The two expression peaks in the leaves of PBC602 appeared at 12 and 48 hpi, respectively, with the highest gene expression in the roots at 72 hpi. Similarly, in the leaves of B27 two peaks were also observed at 48 and 96 hpi, respectively, while in the roots, gene expression did not change a lot, reaching the highest level at $24 \mathrm{hpi}$. The expression level of $\mathrm{CaPO1}$ in leaves and roots of the three cultivars was as follows: CM334 > PBC602 > B27.

The expression of $C a B G L U$ in leaves (Figure 7C) was higher than in the roots of the three cultivars (Figure 7D). The transcription of CaBGLU in the resistant cultivar, C.annuum CM334, was dramatically induced with P. capsici infection. For CM334 leaves, the expression of $C a B G L U$ gene was downregulated and at its lowest level $12 \mathrm{hpi}$, and then it afterwards was upregulated, reaching the highest level at $72 \mathrm{hpi}$. The tendency of the gene expression in the root was different; it showed upregulation and was at its highest level a 72 hpi. For PBC602, gene expression in both leaves and roots reached maximum levels at $48 \mathrm{hpi}$; for B27, the highest gene expression in both leaves and roots occurred at $96 \mathrm{hpi}$. All these findings indicated that the regulation mechanism in leaves and roots was different. The expression level of CaBGLU in leaves and roots of the three cultivars studied was as follows: CM334>PBC602>B27.

Expression levels of $C a B P R 1$ were high in resistant and moderately resistant cultivars (Figure 7E, F).The highest expression level in leaves and roots of CM334 was three times higher than that in resistant cultivar B27. In leaves and roots of CM334, the highest expression level existed respectively at 24 and 48 hpi. The expression tendency was first upregulated, and then downregulated. The highest expression level existed in leaves and roots of PBC602 both at 72 hpi. The highest expression level was in leaves and roots of B27 respectively at 96 and $48 \mathrm{hpi}$.

The highest expression levels of CaRGA2 and CaBPR1 occurred in leaves and roots of CM334 at both 24 and 48 hpi (Figure 7G, H). The gene expression was first upregulated and then downregulated with time; however, the expression level in leaves was higher than that in roots. The highest expression level of $C a R G A 2$ was in leaves and roots of PBC602, respectively at 24 and $12 \mathrm{hpi}$. The highest expression level of $C a R G A 2$ was in leaves and roots of B27 both at $12 \mathrm{hpi}$. The expression level in both of the two tissues (leaves and roots) was basically the same.

\section{DISCUSSION}

\section{Identification of pepper phytophthora blight pathogen}

There has been little research on the identification of pepper Phytophthora blight pathogen until now. By the field observation of pepper Phytophthora blight in Shaanxi, P.R. China, the results obtained showed that the diseases plants had similar symptoms to that in the stage of adulthood of pepper Phytophthora blight, with constricted and browning haulm, wilted leaves, and sparse and white mold layer on the fruit surface. By means of isolation and culture of pepper Phytophthora blight pathogen and morphological observation, we identified the pathogen of pepper Phytophthora blight as Phytophthora capsici Leonia according to Zheng (1997). 


\section{Root activity of the different resistant pepper cultivars}

Root vigor is an important index reflecting the activity of the root system. Whether the plant can maintain the high root vigor in different types of adverse stresses reflects its antiadversity ability (Bai et al., 2012). When the plants were subjected to the stress from P. capsici, the rising root vigor of the plants was a type of self-protection, that is, the plants can keep their roots' normal physiological function by enhancing their root vigor to slow down the pathogenic poisoning. This is also a type of self-protective mechanism stimulated by the stress of $P$. capsici infection. CM334 showed a high level of root vigor at 24 hpi with P. capsici, which indicated that it had a high tolerance to P. capsici. The worse one was PBC602. The root vigor of B27 was one-third as high as the control level at $96 \mathrm{hpi}$, which showed a weak resistance against $P$. capsici. At that time, the stem of the material was obviously dehydrated, constricted and browning, and the leaves were wilting and losing the ability to resist the pathogen.

\section{Changes in peroxidase, phenylalanine ammonia lyase, and $\beta$-1,3-glucanase activities}

When plants are infected by the pathogen, complicated physiological and biochemical changes in the plant will occur to resist the invasion and detriment of pathogen. Some studies have demonstrated that the POD, PAL and $\beta-1,3$-glucanase are closely related to plant resistance. After inoculation with $P$. capsici, different resistant and susceptible cultivars both displayed a resistance mechanism, promoting an enzymatic defense system, involving POD, PAL and $\beta$-1,3-glucanase. The induction of POD, PAL and $\beta$-1,3-glucanase activities lead to the formation of antiseptic secondary products, such as lignin, and stimulate cell death to resist the invasion and expansion of $P$. capsici (Yu et al., 2012). The expression of the corresponding gene of the enzymes was upregulated at the primary stage of inoculation with $P$. capsici, which promoted the regulated mechanism in the plant.

The results showed that the activity of all three enzymes, POD, PAL and $\beta-1,3-$ glucanase, in the different resistant cultivars increased after inoculation with $P$. capsici, basically in accordance with the resistance level of the cultivar. The enzyme activity of the resistant cultivar was highest and was maintained for a longer time, followed by the medium resistant variety. The elevated enzyme activity of the susceptible variety was relatively weak and shortlived. These demonstrated that the resistant variety after being inoculated with $P$. capsici could produce an efficient resistance response to resist the invasion of $P$. capsici, which was consistent with that in the interaction system, Phytophthora melonis (Gao et al., 1998) and Phytophthora Sojae (Zuo et al., 2009). The study on the different protective enzyme activities of the pepper after inoculation with $P$. capsici, can be useful not only for understanding the resistance to the pathogen but also providing a theoretical basis for the identification and selection of pepper germplasm resistance to $P$. capsici, as the index of resistance identification.

\section{Inhibition of the crude enzymes from $\beta-1,3$-glucanase and PAL on $P$. capsici}

On the basis of the direct effect of $\beta$-1,3-glucanase and PAL on the P. capsici, the mixture of enzymes greatly inhibited the $P$. capsici mycelial growth and formation of the sporangium, while the inhibition by the PAL crude enzyme was weaker than $\beta$-1,3-glucanase. It means that the inhibitory effect on the P. capsici was related to $\beta-1,3$-glucanase, which catalyzes the 
degradation of cell wall essential component $\beta$-1,3-glucan. The enzyme mixture enhanced the resistance to $P$. capsici, which suggested that the mixture of the $\beta$-1,3-glucanase and PAL crude enzyme solution had a synergistic interaction in the inhibition of $P$. capsici.

\section{Expression of defense-related genes}

Real-time PCR technology provides new opportunities to detect and study phytopathogenicity (Silvar et al., 2005). Because of its sensitivity, specificity and reproducibility, real-time PCR is suitable for identifying plant pathogens or for detecting minor changes in host resistance and susceptibility.

In this study, susceptible plants and resistant plants were inoculated with the oomycetes of $P$. capsici, to evaluate the expression of genes involved in plant defense responses over time. The results showed that the highest gene expression level of $\mathrm{CaPOI}$ and $\mathrm{CaBGLU}$ occurred in the leaf and root of CM334 both at $72 \mathrm{hpi}$, and what is more, the expression level in the leaves was higher than that in the roots. The gene expression level in medium resistant and susceptible cultivars was relatively lower. It appears that $\mathrm{CaPO1}$ and $\mathrm{CaBGLU}$ can be used as effective proof of the identification of a resistant cultivar. By comparing the gene expression of $\mathrm{CaPOI}$ and $C a B G L U$ in CM334 with POD and $\beta$-1,3-glucanase enzyme activities, we observed that the greatest level of the enzyme activity occurred at 6 and 24 hpi, respectively, which was earlier than that of gene expression. We predicted that it might be caused by the coordinated expression of other genes.

The highest gene expression of CaBPR1 and CaRGA2 in the leaves of CM334 was observed at $24 \mathrm{hpi}$, while in the roots it occurred at $48 \mathrm{hpi}$. The tendency of gene expression was first upward and then downward. The highest gene expression in the leaves occurred earlier and was higher than that in the roots. The gene expression was lower in the medium resistant and susceptible cultivars with no obvious change, which indicated that the gene expression was closely correlated with plant resistance.

The real-time PCR developed here, together with disease severity studies, will enable the selection and breeding of the most resistant cultivars against disease in the future.

\section{ACKNOWLEDGMENTS}

Research supported by the National Natural Science Foundation of China (\#31272163), the "Twelfth Five-Year" Plan of National Science and Technology in Rural Areas (\#2011BAD12B03) and the Shaanxi Provincial Science and Technology Coordinating Innovative Engineering Project (\#2012KTCL02-09).

\section{REFERENCES}

Bai YZ, Xie YH, Chen CC, Zhang XH, et al. (2012). Effect of Pb on root's growth and activity of 14 native herbaceous plants. J. Irrigat. Drain. 31: 75-77.

Baysal O, Turgut C and Mao G (2005). Acibenzolar-S-methyl induced resistance to Phytophthora capsici in pepper leaves. Biol. Plant 49: 599-604.

Benkeblia N (2000). Phenylalanine ammonia-lyase, peroxidase, pyruvic acid and total phenolics variations in onion bulbs during longterm storage. Lebensm. Wiss. Technol. 33: 112-116.

Biles CL, Brunton BD, Wall MM and Rivas M (1995). Phytophthora capsici zoospore infection of pepper fruit in various physical environments. Proc. Okla. Acad. Sci. 75: 1-5. 
Black LL, Green SK, Hartman GL and Poulos JM (1991). Pepper Diseases: A Field Guide. Asian Vegetable Research and Development Center (AVRDC), Shanhua, Taiwan.

Candole BL, Conner PJ, McGregor C, Waters V, et al. (2012). The disease reactions of heirloom bell pepper "California Wonder" to Phytophthora capsici. Agr. Sci. 3: 417-424.

Chen M and McClure JW (2000). Altered lignin composition in phenylalanine ammonia-lyase-inhibited radish seedlings: implications for seed-derived sinapoyl esters as lignin precursors. Phytochemistry 53: 365-370.

Chittoor JM, Leach JE and White FF (1999). Induction of Peroxidase During Defense Against Pathogens. Pathogenesis Related Proteins in Plants. CRC Press, Boca Raton.

Cloud AME and Deverall BJ (1987). Induction and expression of systemic resistance to the anthracnose disease in bean. Plant Pathol. 36: 551-557.

D’Cunha GB, Satyanaraan V and Nair PM (1996). Stabilization of phenylalanine ammonia lyase containing Rhodotorula glutinis cells for the continuous synthesis of L-phenylalanine methyl ester. Enzyme Microb. Technol. 19: 421-427.

Egea C, Dickinson MJ, Candela M and Candela ME (1999). $\beta$-1,3-glucanase isoenzymes and genes in resistant and susceptible pepper (Capsicum annuum) cultivars infected with Phytophthora capsici. Physiol. Plantarum 107: 312-318.

Funnell DL, Lawrence CB, Pedersen JF and Schardl CL (2004). Expression of the tobacco $\beta$-1,3-glucanase gene, PR-2d, following induction of SAR with Peronospora tabacina. Physiol. Mol. Plant Pathol. 65: 285-296.

Gao MY, Jiang P and Li G (1998). Study on the changes of several enzyme activities of Xinjiang Melon induced by glucanase in induced chickpea. Curr. Sci. 89: 659-663.

Hammerschmidt R, Nucklesa EM and Kuća J (1982). Association of enhanced peroxidase activity with induced systemic resistance of cucumber to Colletotrichum lagenarium. Physiol. Mol. Plant Pathol. 20: 73-76.

Hausbeck MK and Lamour KH (2004). Phytophthora capsici on vegetable crops: research progress and management challenges. Plant Dis. 88: 1292-1303.

Holmes GJ, Lancaster ME, Rodriguez RJ and Redman RS (2001). Relative susceptibility of cucurbit and solanaceous crops to Phytophthora blight. Phytopathology 91 (Suppl 6): S39.

Hwang BK and Kim CH (1995). Phytophthora blight of bell pepper and its control in Korea. Plant Dis. 79: 221-227.

Idoia G, Jone A and Nieves G (2006). Defence-related enzymes in pepper roots during interactions with arbuscular mycorrhizal fungi and/or Verticillium dahliae. BioControl 51: 293-310.

Jung WJ, Jin YL, Kim YC, Kim KY, et al. (2004). Inoculation of Paenibacillus illinoisensis alleviates root mortality, activates of lignification-related enzymes, and induction of the isozymes in pepper plants infected by Phytophthora capsici. Biol. Control 30: 645-652.

Kolattukudy PE, Mohan R, Bajar MA and Sherf BA (1992). Plant peroxidase gene expression and function. Biochem. Soc. Trans. 20: 333-337.

Kombrink E and Somssich IE (1995). Defense responses of plants to pathogens. Adv. Bot. Res. 21: 1-34.

Kousik CS, Donahoo RS and Hassell R (2012). Resistance in watermelon rootstocks to crown rot caused by Phytophthora capsici. Crop Protect. 39: 18-25. 39: 18-25.

Lee BK, Kim BS, Chang SW and Hwang BK (2001). Aggressiveness to pumpkin cultivars of isolates of Phytophthora capsici from pumpkin and bell pepper. Plant Dis. 85: 497-500.

Oelke LM and Bosland PW (2003). Differentiation of race specific resistance to Phytophthora root rot and foliar blight in Capsicum annuum. J. Am. Soc. Hort. Sci. 128: 213-218.

Ristaino JB and Johnston SA (1999). Ecologically based approaches to management of Phytophthora blight on bell pepper. Plant Dis. 83: 1080-1089.

Saikia R, Singh BP, Kumar R and Arora DK (2005). Detection of pathogenesis-related proteins-chitinase and beta-1, $\beta$ glucanase in induced chickpea. Curr. Sci. 89: 659-663.

Silvar C, Diaz J and Merino F (2005). Real-time polymerase chain reaction quantification of Phytophthora capsici in different pepper genotypes. Phytopathology 95: 1423-1429.

Suo YY and Leung DWM (2001). Elevation of extracellular $\beta$-1,3-glucanase and chitinase activities in rose in response to treatment with acibenzolar-S-methyl and infection by D. rosae. J. Plant Physiol. 158: 971-976.

Tyler BM (2002). Molecular basis of recognition between phytophthora pathogens and their hosts. Annu. Rev. Phytopathol. 40: $137-167$

Wakelin AM and Leung DWM (2009). $\beta$-1,3-glucanase activity in the stigma of healthy petunia flowers. Biol. Plantarum 53: 69-74.

Wang YL, Ma FW, Li MJ and Liang D (2011). Physiological responses of kiwi fruit plants to exogenous ABA under drought conditions. Plant Growth Regul. 64: 63-74.

Wu CT and Bradford KJ (2003). Class I chitinase and $\beta$-1,3-glucanase are differentially regulated by wounding, methyl jasmonate, ethylene, and gibberellin in tomato seeds and leaves. Plant Physiol. 133: 263-273. 
Yeom SI, Baek HK, Oh SK, Kang WH, et al. (2011). Use of a secretion trap screen in pepper following Phytophthora capsici infection reveals novel functions of secreted plant proteins in modulating cell death. Mol. Plant Microb. Interact. 24: 671-684.

Yu HJ, Zhu DW, Liu LJ, Tang XF, et al. (2012). PAL and POD activities of soybean hypocotyls infected by Pythium. Soybean Sci. 31: 495-497.

Zheng XB (1997). Phytophthora and its Research Techniques. Agricultural Press, Beijing, 10-132.

Zuo YH, Zang ZJ and Liu TR (2001). Studies on production condition of zoospores of Phytophthora sojae. Acta Phytopathol. Sin. 31: 241-245.

Zuo YH, Kang Z.SH, Yang CH, Rui HY, et al. (2009). Relationship between activities of $\beta$-1,3-glucanase and chitinase and resistance to phytophthora root rot in soybean. Acta Phytopathol. Sin. 39: 600-607. 